\title{
Effect of UV irradiation, sample thickness and storage temperature on storability, bacterial activity and functional properties of liquid egg
}

\author{
S. Abdanan Mehdizadeh • S. Minaei • \\ M. A. Karimi Torshizi • E. Mohajerani
}

Revised: 13 August 2013 / Accepted: 25 August 2013 / Published online: 30 August 2014

(C) Association of Food Scientists \& Technologists (India) 2014

\begin{abstract}
Effect of sample thickness, ultraviolet irradiation and storage temperature on bacterial activity, storability and functional properties (foamability and stability) of liquid egg were investigated. Eggs were contaminated with prepared Salmonella suspension $108 / \mathrm{mL}$. Separated albumen and yolk samples were poured in three thicknesses $(1,2$ and $3 \mathrm{~mm})$ and irradiated at 3,510,15 min with ultraviolet radiation and were stored at $5,15,25,37^{\circ} \mathrm{C}$ for up to 8 days. Observations indicated that all ultraviolet irradiation times, reduced the total count of Salmonella bacteria in egg samples. Although, functional properties were improved, protein oxidation in both albumen and yolk increased. After the first 2 days of storage, total counts of Salmonella and protein oxidation of eggs decreased solely in the $5{ }^{\circ} \mathrm{C}$ treatment. It is concluded that irradiation treatment can be used to decrease bacterial contamination of liquid egg albeit not below the safe level for raw consumption. Furthermore, the best irradiation times to improve foam ability and stability were 10 and $5 \mathrm{~min}$, respectively.
\end{abstract}

Keywords Liquid egg (yolk and albumen) · Bacterial safety · Protein oxidation · Durability

\author{
S. Abdanan Mehdizadeh $(\triangle)$ \\ Department of Agricultural Machinery, College of Agricultural \\ Engineering, Ramin Khuzestan University of Agriculture and \\ Natural Resources, Mollasani, Ahvaz, Khuzestan, Iran \\ e-mail: saman.abdanan@gmail.com

\section{S. Minaei} \\ Faculty of Agriculture, Department of Agricultural Machinery \\ Engineering, Tarbiat Modares University, Tehran, Iran \\ M. A. Karimi Torshizi \\ Faculty of Agriculture, Department of Poultry Science, Tarbiat \\ Modares University, Tehran, Iran \\ E. Mohajerani \\ Department of Physics, Shahid Beheshti University, Tehran, Iran
}

\section{Introduction}

The quality of food products is determined by chemical composition, physical properties, and level of microbiological and toxicological contaminants, shelf-life, packaging, and labeling (Probola and Zander 2007). Among of all these factors, microbiological and toxicological contaminants have crucial importance due to their impact on human life. Therefore, illness attributed of raw food materials to contaminate other food products, directly and indirectly, is perhaps the most prevalent health problem in the present world and is an important cause of dwindled economic productivity (Redmond and Griffith 2003). Egg is widely consumed in a daily diet in many countries. Meanwhile, due to its numerous special functional properties such as foamability, foamstability, thickening, coating, colour, emulsifying and control of crystallization it has greatly been used to the egg-breaking industry (Meszaros et al. 2006). Among the functional properties foamability is one of the most important functions of albumen proteins in the production of bakery products. Many studies have been done to improve foamability of albumen using heating or high pressure treatment, with emphasis on the relationship between the structural properties of albumen proteins and their functional properties (Van der Plancken et al. 2005; Perez and Pilosof 2003).

Although, foods must not contain any pathogens or infections the presence of pathogenic bacteria such as Salmonella and Campylobacter in poultry and poultry products is a common phenomenon (Molins et al. 2001). The egg becomes contaminated either prior to oviposition, with the source of contamination originating in the egg-laying apparatus of the bird, or after oviposition by penetrationmoist feces of the shell (Badr 2006). To ensure microbial safety, improve shelf-life of liquid egg several operations such as disinfection, fumigation, egg washing and grading are employed. These methods are effective against post-laying contamination. Although, the 
only control measure against internal infection in shell eggs is pasteurization (Al-bachir and Zeinou 2006), such enhanced heat treatments applied to liquid egg could, first, result in denaturation of proteins leading to decreased functional properties and, second, cause extensive droplet or protein aggregation, and undesired emulsion gelation (Anton et al. 2001). By all these considerations, only commercial processes which manufacturers presently prefer, are pasteurization and/or sterilization treatments (Serrano et al. 1997). As an alternative for heat treatment food irradiation provides significant advantages to food producers by destroying harmful pathogens and extending shelf life of foodstuffs (Durante 2002; Morehouse 2002). Irradiation is a non-thermalmethod that can eliminate foodborne pathogens such as Salmonella, Escherichia coli and Listeria both inside and on the surface of shell eggs. However, irradiation may produce free radicals that can cause significant changes in quality and functional properties of egg and egg products. In this regard, Liu et al. (2009) reported that Salmonella typhimurium inoculated on egg shell was not detected by irradiation while, using irradiation improved functional properties for further processing and efficient separation of egg albumen and yolk. The objective of this study was to assess the effects of irradiation time, sample thickness and storage temperature on the microbial safety, protein oxidation, functional properties and storability of liquid egg (albumen and yolk).

\section{Material and methods}

\section{Sample preparation}

For the preparation of this experimental 1-day-old, clean, white-shell, fresh, unwashed and unfertile chicken eggs were collected from one flock of 45-week old Hyline hens which received the same standard diet. The averages of some physical and chemical properties of ten eggs measured at day zero are given in Table 1. All damaged or cracked eggs were discarded. Samples were manually broken, and after separation into albumen (the egg white) and yolk, each was manually mixed. Thoroughly mixed yolk was carefully cleaned of the adhering white and the liquid yolk was collected into a beaker by puncturing the vitelline membrane (Ma et al. 1990; Anton et al. 2001). Each mixed sample was divided into $30 \mathrm{~g}$ portions immediately sealed to prevent evaporation of moisture and was kept for irradiation treatment.

Irradiation

Samples were exposed to UVradiation for 3, 5, 10 and $15 \mathrm{~min}$ using an experimental irradiator (Tekban, 320, Iran) with the samples placed $25 \mathrm{~cm}$ from the $254 \mathrm{~nm}$ UV light source. The UV dose used was $0.75^{*} 10^{\wedge} 3 \mathrm{~J} \mathrm{~m}^{-2}$ (Piga et al. 1997). Samples were poured in 1, 2 and $3 \mathrm{~mm}$ thicknesses then irradiation was carried out at room temperature in isolated and bacterial free environment. Due to the surface penetration property of UV, during treatment, samples were stirred three times, to receive a uniform dosage.

\section{Bacterial analysis}

Two-gram samples of liquid eggs were artificially contaminated with a suspension of Salmonella by thorough mixing (Blumenthal 1990). The suspension was prepared by mixing a sufficient colony culture of Salmonella with pure peptone water media. The ratio of inoculation was $1 \mathrm{~mL}$ of suspension to $9 \mathrm{~mL}$ of egg. Salmonella count in the prepared suspension was determined using a spectrophotometer at $620 \mathrm{~nm}$ wavelength (Eppendorf Biophotometer Plus, Germany). The total count according to its absorbance was $10^{8} / \mathrm{mL}$. Subsequently, serial dilutions were carried out based on the standard methods in order to make enumeration easier (AOAC 1996). The medium used for the bacterial investigation was nutrient agar. Eggs treated with UV radiation were stored at $5,15,25$, and $37{ }^{\circ} \mathrm{C}$. The survival level of Salmonella, after incubation at $37{ }^{\circ} \mathrm{C}$ for $48 \mathrm{~h}$, in both irradiated and control samples was determined by plate counting conducted every 2 days for a total of 6 days. The Salmonella load one log cycle $\left(\mathrm{D}_{10}\right)$ value was then calculated.

\section{Protein oxidation}

Protein oxidation was determined using the method of Vuorela et al. (2005) with slight modification for egg. Onegram samples of yolk and albumen were homogenized with $19 \mathrm{~mL}$ deionized water using homogenizer for 60s. five hundred microliters of homogenate was transferred into two $1.5 \mathrm{~mL}$ microtubes, where $0.5 \mathrm{~mL}$ of $10 \%$ trichloroacetic acid (TCA) was added to each. The sample was centrifuged for
Table 1 Physical and chemical properties of 1-day-old eggs

\begin{tabular}{llll}
\hline Large diameter & $57.665(\mathrm{~mm})$ & Haugh Unit & 86.58 \\
Short diameter & $43.75(\mathrm{~mm})$ & albumen and yolk weight difference & $14.59(\mathrm{~g})$ \\
Shell thickness & $31.05(\mathrm{~mm})$ & Color & 11.5 \\
Break force & $3.4801(\mathrm{~N})$ & Total Weight & $60.989(\mathrm{~g})$ \\
albumen $\mathrm{pH}$ & 8.662 & Yolk weight & $15.175(\mathrm{~g})$ \\
Yolk $\mathrm{pH}$ & 6.115 & Yolk height & $14.355(\mathrm{~mm})$ \\
\hline
\end{tabular}


Table 2 Results of the analysis of variance of bacterial count for albumen and yolk

\begin{tabular}{lllr}
\hline Source of variation & DF & $\begin{array}{l}\text { MS } \\
\text { Bacterial count for albumen }\end{array}$ & Bacterial count for yolk \\
\hline Thickness & 2 & $0.13175242^{* *}$ & $0.00724199^{\mathrm{ns}}$ \\
Irradiation time & 4 & $2.82530757^{* *}$ & $8.30956469^{* *}$ \\
Storage & 3 & $5.66504117^{* *}$ & $13.71659642^{* *}$ \\
Irradiation time*thickness & 8 & $0.40295664^{* *}$ & $0.83777042^{\mathrm{ns}}$ \\
Storage*Irradiation time & 12 & $0.37354869^{* *}$ & $1.23642708^{*}$ \\
Thickness*storage & 6 & $0.32816853^{* *}$ & $1.84850816^{*}$ \\
Irradiation* storage*thickness & 24 & $0.06204024^{* *}$ & $0.37079352^{\mathrm{ns}}$ \\
\hline
\end{tabular}

$*$ and $* *$ Significant at 5 and $1 \%$ levels, respectively

$n s$ not significant

$10 \mathrm{~min}$ at 3,000 $\mathrm{g}$, and the supernatant was removed. Two different measurements were carried out for protein oxidation: (a) carbonyl quantification and (b) protein quantification. For sample (a) $1 \mathrm{~mL}$ of 2, 4-dinitrophenyl hydrazine (DNPH), and for sample (b) $1 \mathrm{~mL}$ of $2 \mathrm{M} \mathrm{HCl}$ was added. After incubation for $1 \mathrm{~h}$ (shaken every $20 \mathrm{~min}$ ), $1 \mathrm{~mL}$ of TCAwas added to both samples. The sample was vortexed and centrifuged for $10 \mathrm{~min}$ at 3,000 g. Supernatant was taken away carefully without damaging the sediment using the sampler. The sediment was washed with $0.5 \mathrm{~mL}$ of ethanol/ethyl acetate (1:1), then shaken, and centrifuged for $5 \mathrm{~min}$ at 10,000 rpm. This procedure was repeated two to three times to make it as pure as possible, after which, the sediment was thoroughly dried with nitrogen. The sediment was dissolved in $2 \mathrm{~mL}$ of guanidine hydrochloride $(\mathrm{GH})$, shaken, and centrifuged for $10 \mathrm{~min}$ at 3,000 g. Amounts of carbonyls (sample a) and protein concentration (sample b) were determined using spectrophotometer at 370 and $280 \mathrm{~nm}$, respectively. Samples were subjected to this procedure, according to the results of bacterial analysis only for the $5{ }^{\circ} \mathrm{C}$ treatment, periodically at 2-day intervals for a total of 8 days. Sample stored at 15,25 and $37{ }^{\circ} \mathrm{C}$ were not followed up since unacceptable increase in bacterial load were observed.

To measure protein concentrations in sample (b) a standard solution of bovine serum albumin (BSA) in $20 \mathrm{mM}$ sodiumphosphate buffer with $6 \mathrm{M}$ guanidine hydrochloride (pH 6.5) was prepared, and it was qualified by standard curve. Concentration (nanomolar) of carbonyls was calculated as

Carbony $_{\text {nanomolar }}=\left[\frac{A b s_{370 \mathrm{~nm}}}{21.0 \mathrm{mMCm}}\right] \times 1000$

Where $21.0 \mathrm{mM}^{-1} \mathrm{~cm}^{-1}$ is the molar extinction coefficient of carbonyls. The inhibition coefficient of protein carbonyls formation is calculated as follows:

$C I C=\frac{C_{0}-C_{t}}{C_{0}} \times 100$
Where $\mathrm{C}_{0}$ is the concentration (nanomolar) of protein carbonyls per mg of protein in a control sample and $\mathrm{C}_{1}$ is the concentration of protein carbonyls per $\mathrm{mg}$ of protein in a tested sample. The inhibitions were expressed as percentages.

Functional properties

Thirty milliliter samples of irradiated and non irradiated liquid egg were placed into $100 \mathrm{ml}$ cylinders and whipped for $30 \mathrm{~s}$ using a homogenizer at $1,900 \mathrm{rpm}$. Foaming ability is defined as the foam volume ( $\mathrm{ml}$ ) measured $1 \mathrm{~min}$ after the end of whipping as follows (Hidalgo et al. 2008; Song et al. 2009):

Foamability $(\%)=\left[\left({ }^{\mathrm{V}-\mathrm{V}_{0}} / \mathrm{v}_{0}\right)\right] \times 100$

Where $\mathrm{V}$ is the foam volume and $\mathrm{V}_{\mathrm{o}}$ is the whole egg sample volume before whipping. Foam stability was evaluated immediately after whipping. Foam was gently poured into a $250 \mathrm{ml}$ graduated plastic cone and the weight of the transferred foam was recorded. The cone was covered with a transparent film and kept at $4{ }^{\circ} \mathrm{C}$ for $2 \mathrm{~h}$, and then the volume of the liquid separated at the cone bottom was noted. Foam stability was calculated as follows (Rossi et al. 2010):

Stability $(\%)=\left[1-\mathrm{V}_{\mathrm{LS}} / 100 \mathrm{~V}_{\mathrm{LWE}}\right] \times 100$

Table 3 Comparison of the means of bacterial load as affected by irradiation time

\begin{tabular}{lll}
\hline Irradiation time (min) & $\begin{array}{l}\text { Bacterial count } \\
\text { for albumen }\end{array}$ & $\begin{array}{l}\text { Bacterial count } \\
\text { for yolk }\end{array}$ \\
\hline 0 & $7.06500^{\mathrm{a}}$ & $7.2128^{\mathrm{a}}$ \\
3 & $6.56869^{\mathrm{c}}$ & $6.7271^{\mathrm{b}}$ \\
5 & $6.69510^{\mathrm{b}}$ & $6.6000^{\mathrm{b}}$ \\
10 & $5.78409^{\mathrm{e}}$ & $5.8709^{\mathrm{c}}$ \\
15 & $6.03892^{\mathrm{d}}$ & $6.25946^{\mathrm{b}}$ \\
\hline
\end{tabular}

Means with the same letter are not significantly different 


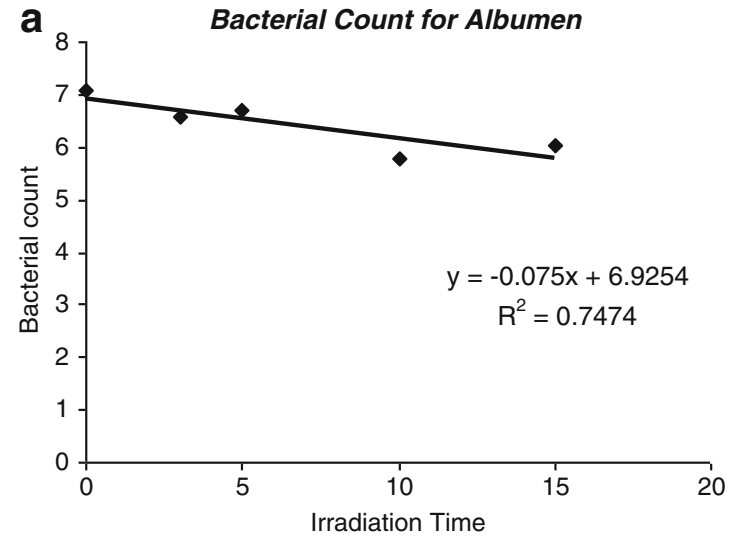

Fig. 1 Effect of irradiation on bacterial load for albumen (a) and yolk (b)

Where $\mathrm{V}_{\mathrm{LS}}$ is the volume of the separated liquid and $\mathrm{V}_{\mathrm{LWE}}$ is the volume of the liquid whole egg, corresponding to the equivalent volume of the transferred foam and calculated by dividing the initial foam weight by whole egg density.

\section{Statistical analysis}

All the experiments were replicated three times and the data were statistically analyzed using SAS institute Inc.. The effects of irradiation time and thickness on bacterial activity, storability and protein oxidation were determined using the analysis of variance and Duncan's multiple range test.

\section{Results and discussion}

\section{Microbial safety}

As shown in Table 2, effects of sample thickness, irradiation time, storage time and their interactions on bacterial count were significant $(P<0.001)$ for albumen. But for yolk, only the effect of storage time, and irradiation time were significant $(P<0.001)$. Samples treated with UV radiation had significantly $(P<0.001)$ lower total Salmonella count compared with the control samples for both albumen and yolk. Neither thickness nor interaction effects of irradiation and thickness could significantly $(P>0.05)$ affect the bacterial count in samples of

Table 4 Results of Duncan's Multiple Range Test on the effects of thicknesses on bacterial count

Thickness (mm) Bacterial count for albumen Bacterial count for yolk

\begin{tabular}{lll}
\hline 1 & $6.59414^{\mathrm{b}}$ & $6.6073^{\mathrm{a}}$ \\
2 & $6.60573^{\mathrm{b}}$ & $6.6076^{\mathrm{a}}$ \\
3 & $6.68048^{\mathrm{a}}$ & $6.5884^{\mathrm{a}}$ \\
\hline
\end{tabular}

Number with the same letter are not significantly different

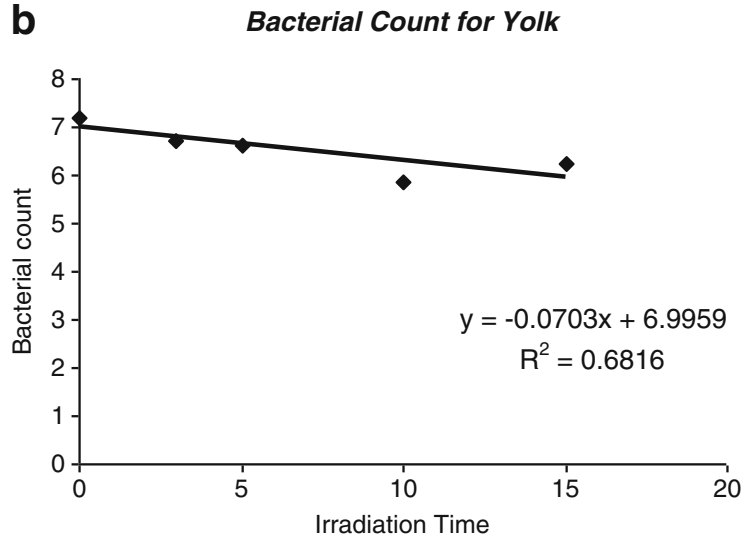

liquid egg yolk. This is due probably to a decrease in UV penetration into the thicker samples of liquid yolk.

As shown in Table 3 increasing UV irradiation significantly reduced bacterial load on albumen $(P<0.05)$. Although, for yolk, there were no significant differences in bacterial count for 3, 5, and 15 min irradiation times, the bacterial count of eggs significantly $(P<0.05)$ decreased compared with the control. Furthermore, based on observations, 10 min irradiation for both albumen and yolk was the best time in which bacterial count effectively diminished.

Compared to the non-irradiated liquid eggs in the presence of Salmonella for albumen, bacterial count in 3, 5, 10, and $15 \mathrm{~min}$ irradiation were lower by $0.4857,0.6128,1.3419$, and $0.9628 \mathrm{log}$ $\mathrm{cfu} / \mathrm{g}$, respectively. Moreover, the presence of Salmonella for yolk in 3, 5, 10, and 15 min irradiation were 0.49631, 0.3699, 1.28091 , and $1.025 \mathrm{log} \mathrm{cfu} / \mathrm{g}$ lower than control values, respectively. Meanwhile, this reduction either for albumen or for yolk showed fairly linear trends with $R^{2}=0.68$ for albumen and 0.74 for yolk. The higher value of R2 was observed for liquid yolk than for albumen. This could be ascribed to the insignificant decrease of bacterial count for liquid yolk (Fig. 1). ${ }^{1}$

Because of the aggregate characteristic of yolk, effect of thickness on bacterial count was not significant (Table 4). However, for albumen, bacterial count in the $3 \mathrm{~mm}$ thickness treatment significantly increased in comparison with that of the control. Contrary to our expectation, thickness was not a prominent parameter therefore it need not be taken into account in liquid egg processing.

According to Table 5, bacterial counts of albumen and yolk initially tend to decrease on the second day before increasing afterwards and reaching maximum values after 4 days of storage at $5{ }^{\circ} \mathrm{C}$.

During the first 2 days of storage, there was a sudden decrease in bacterial count which is clearly and strongly dependent on irradiation; afterward, there was a sharp increase in bacterial load and figures showed upward trend (Fig. 2).

\footnotetext{
${ }^{1}$ Although, the best fit for bacterial count was a fourth order polynomial $\left(R^{2}=1\right)$, for the sake of simplicity, linear forms were preferred.
} 
Table 5 Results of Duncan's multiple range test on the effects of storage on bacterial count

\begin{tabular}{lll}
\hline Storage time (day) & $\begin{array}{l}\text { Bacterial count } \\
\text { for albumen }\end{array}$ & Bacterial count for yolk \\
\hline 1 & $6.48625^{\mathrm{c}}$ & $7.0035^{\mathrm{b}}$ \\
2 & $5.20631^{\mathrm{d}}$ & $5.8287^{\mathrm{d}}$ \\
3 & $6.79829^{\mathrm{b}}$ & $6.5768^{\mathrm{c}}$ \\
4 & $7.01628^{\mathrm{a}}$ & $7.4953^{\mathrm{a}}$ \\
\hline
\end{tabular}

Number with the same letter are not significantly different

Our fluctuating results are compatible with Nigro et al. (2000) who found that UV 0.50 and $1.00 \mathrm{~kJ} \mathrm{~m}^{-2}$ doses of radiation treatment significantly reduced $B$. cinerea arising from both artificial inoculation and natural Infection of strawberries in comparison with the non-irradiated control. Furthermore, strawberries irradiated with 0.50 and $1.00 \mathrm{~kJ} \mathrm{~m}^{-2}$ after $12 \mathrm{~h}$ of inoculation, showed lower infection percentage than the control and 24 and $48 \mathrm{~h}$ inoculations.

Ultraviolet irradiation significantly decreases bacterial count for both albumen and yolk $(P<0.05)$. Immediately after irradiation (day zero), 3 and 15 min treatments, reduced Salmonella in albumen and yolk by 0.95 and $0.98 \mathrm{log}$, respectively. After 2 days of storage, in the 15 min irradiation for $3 \mathrm{~mm}$, Salmonella in albumen reduced to less than $3 \log \mathrm{cfu} / \mathrm{g}$. Therefore, 15 and $10 \mathrm{~min}$ appeared to be optimum irradiation times for improving microbial safety of albumen and yolk, respectively.

Results in Table 6 show that bacterial load in irradiated liquid eggs after 2 days of storage decreased significantly for each irradiation time within each group of storage period $(P<0.05)$. These results are in agreement with those reported by Badr (2006). Total Salmonella count for $3 \mathrm{~mm}$ thick yolk samples irradiated for 10 min not only was minimum $(2.4 \mathrm{cfu} / \mathrm{g})$ but also had a lower range in comparison with that of albumen.

Our observations are in line with those of Serrano et al. (1997) who found that gamma irradiation of eggs is effective

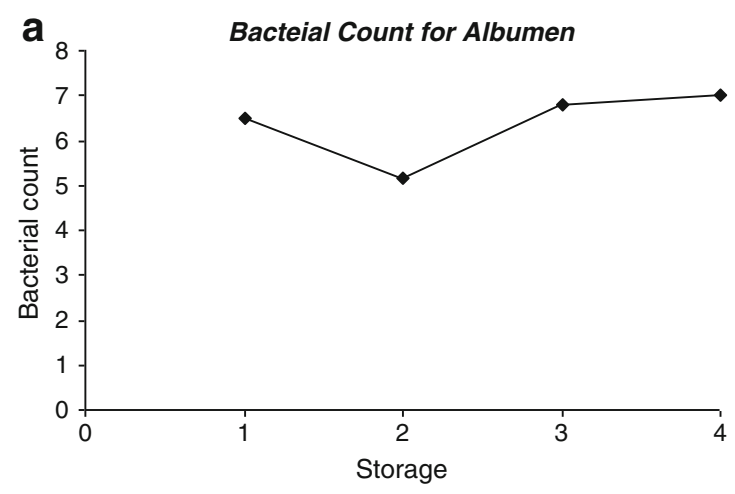

Fig. 2 Effect of storage on bacterial count for albumen (a) and yolk (b) in reducing or eliminating Salmonella enteritidis. Also, Koehler et al. (1989) reported that irradiation dose of $1 \mathrm{kGy}$ eliminates about $100-1,000$ salmonellae $/ \mathrm{kg}$ of whole egg powder. This conforms to the results of the present study which indicated that bacterial count of separated albumen and yolk significantly decreased when the latter were irradiated for $3,5,10$, and $15 \mathrm{~min}$ with UV radiation. Our results indicated that the best radiation times for decreasing bacterial activity were 15 and $10 \mathrm{~min}$ for albumen and yolk in $3 \mathrm{~mm}$ thickness, respectively (Table 7). Although, UV irradiation reduced the Salmonella load, but bacterial contamination was still high enough to indicate that raw liquid eggs are unsafe for human consumption. Therefore, UV radiation was insufficient for complete disinfection of pathogens in liquid eggs, and such eggs are unfit for raw consumption according to the published microbiological criteria for liquid egg products, which stated maximum acceptable levels for the total plate count and enterobacteriaceae as $10^{5}$ and $10^{2} \mathrm{cfu} / \mathrm{ml}$, respectively (Anonymous 1993). In addition, the absence of Salmonella in the liquid egg products may not make them microbiologically suitable for preparing safe uncooked foods (Anonymous 1993). Furthermore, due to the dramatic increase in bacterial load at all other temperatures, the only suitable temperature for storage of liquid egg was $5{ }^{\circ} \mathrm{C}$, i.e. normal refrigeration.

Effect of UV irradiation on protein oxidation for albumen and yolk

Due to the drastic increase of bacterial load at storage temperatures of 15,25 , and $37^{\circ} \mathrm{C}$, protein oxidation tests have been solely carried out at $4{ }^{\circ} \mathrm{C}$. As shown in Table 8, effects of UV irradiation, thickness, storage time, and their interactions on protein oxidation for albumen and yolk were all significant.

Effects of irradiation time, storage and thickness on protein oxidation are shown in Tables 9, 10, and 11, respectively.

Carbonyl content can be considered as a marker for protein oxidation because amino acid residues of proteins, such as

b

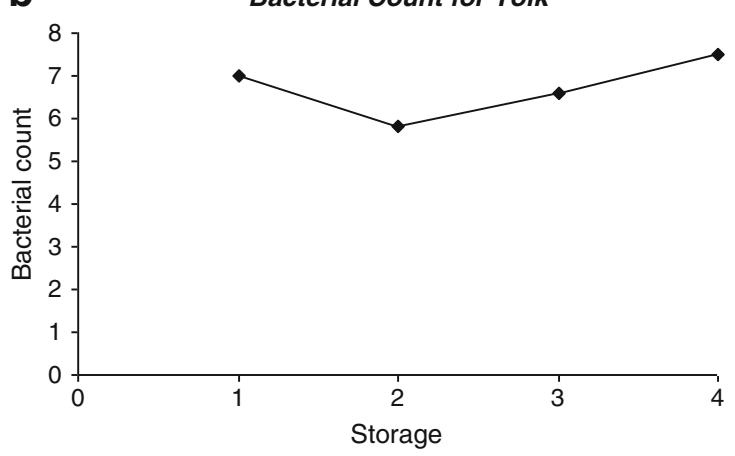


Table 6 Interaction effect of irradiation and storage time on bacterial activity

\begin{tabular}{|c|c|c|}
\hline Irradiation time * day & $\begin{array}{l}\text { Bacterial count } \\
\text { for albumen }\end{array}$ & $\begin{array}{l}\text { Bacterial count } \\
\text { for yolk }\end{array}$ \\
\hline 0 (min) $^{*} 1$ (day) & $6.9500^{\text {ced }}$ & $7.0969^{\mathrm{abc}}$ \\
\hline $0 * 2$ & $6.5400^{\mathrm{fg}}$ & $6.7432^{\text {bcde }}$ \\
\hline $0 * 3$ & $7.2200^{\mathrm{b}}$ & $7.3428^{\mathrm{ab}}$ \\
\hline $0 * 4$ & $7.5500^{\mathrm{a}}$ & $7.6683^{\mathrm{a}}$ \\
\hline $3 * 1$ & $6.2737^{\mathrm{h}}$ & $7.1319^{\mathrm{abc}}$ \\
\hline $3 * 2$ & $6.2623^{\mathrm{h}}$ & $6.0252^{\mathrm{ef}}$ \\
\hline $3 * 3$ & $6.8384^{\mathrm{ed}}$ & $6.7565^{\text {bcde }}$ \\
\hline $3 * 4$ & $7.0249^{\mathrm{bcd}}$ & $7.0450^{\mathrm{abc}}$ \\
\hline $5 * 1$ & $6.3322^{\mathrm{gh}}$ & $7.1044^{\mathrm{abc}}$ \\
\hline $5 * 2$ & $6.4346^{\mathrm{gh}}$ & $6.0918^{\mathrm{def}}$ \\
\hline $5 * 3$ & $6.8929^{\text {ced }}$ & $6.4243^{\text {cedf }}$ \\
\hline $5 * 4$ & $7.1208^{\mathrm{bc}}$ & $7.0330^{\mathrm{abc}}$ \\
\hline $10 * 1$ & $6.3326^{\mathrm{gh}}$ & $6.7972^{\text {bcde }}$ \\
\hline $10 * 2$ & $5.8953^{\mathrm{i}}$ & $4.2808^{\mathrm{g}}$ \\
\hline $10 * 3$ & $6.7535^{\mathrm{ef}}$ & $5.9059^{\mathrm{f}}$ \\
\hline $10 * 4$ & $6.9263^{\mathrm{ced}}$ & $6.4997^{\text {cdef }}$ \\
\hline $15 * 1$ & $6.5427^{\mathrm{fg}}$ & $6.8870^{\mathrm{abcd}}$ \\
\hline $15 * 2$ & $5.6993^{\mathrm{i}}$ & $6.0026^{\mathrm{ef}}$ \\
\hline $15 * 3$ & $6.2867^{\mathrm{h}}$ & $6.4548^{\text {cdef }}$ \\
\hline $15 * 4$ & $6.4594^{\mathrm{gh}}$ & $6.7304^{\text {bcde }}$ \\
\hline
\end{tabular}

Number with the same letter are not significantly different

Table 7 Duncan's Multiple Range Test results for interaction effect of irradiation and thickness on bacterial load

\begin{tabular}{lll}
\hline Irradiation time * thickness & $\begin{array}{l}\text { Bacterial count } \\
\text { for albumen }\end{array}$ & $\begin{array}{l}\text { Carbonyl } \\
\text { for yolk (nmol) }\end{array}$ \\
\hline $0(\min ) * 1(\mathrm{~mm})$ & $7.06500^{\mathrm{a}}$ & $7.2295^{\mathrm{a}}$ \\
$0 * 2$ & $7.06500^{\mathrm{a}}$ & $7.1794^{\mathrm{a}}$ \\
$0 * 3$ & $7.06500^{\mathrm{a}}$ & $7.2295^{\mathrm{a}}$ \\
$3 * 1$ & $6.4887^{\mathrm{cd}}$ & $6.6312^{\mathrm{abc}}$ \\
$3 * 2$ & $6.4267^{\mathrm{d}}$ & $6.6977^{\mathrm{abc}}$ \\
$3 * 3$ & $6.5368^{\mathrm{cd}}$ & $6.8526^{\mathrm{ab}}$ \\
$5 * 1$ & $6.5253^{\mathrm{cd}}$ & $6.6412^{\mathrm{abc}}$ \\
$5 * 2$ & $6.6351^{\mathrm{bcd}}$ & $6.6361^{\mathrm{abc}}$ \\
$5 * 3$ & $6.9248^{\mathrm{ab}}$ & $6.5065^{\mathrm{abc}}$ \\
$10 * 1$ & $6.3767^{\mathrm{de}}$ & $6.2804^{\mathrm{bcd}}$ \\
$10 * 2$ & $6.56869^{\mathrm{bc}}$ & $5.8526^{\mathrm{cd}}$ \\
$10 * 3$ & $6.8060^{\mathrm{abc}}$ & $5.4798^{\mathrm{d}}$ \\
$15 * 1$ & $6.5149^{\mathrm{cd}}$ & $6.2543^{\mathrm{bcd}}$ \\
$15 * 2$ & $6.3785^{\mathrm{de}}$ & $6.6720^{\mathrm{abc}}$ \\
$15 * 3$ & $6.0697^{\mathrm{e}}$ & $6.8737^{\mathrm{ab}}$ \\
\hline
\end{tabular}

Number with the same letter are not significantly different
Table 8 Analysis of variance of protein oxidation data for albumen and yolk

\begin{tabular}{|c|c|c|c|}
\hline \multirow[t]{2}{*}{ Source of variation } & \multirow[t]{2}{*}{ DF } & \multicolumn{2}{|l|}{ Mean square } \\
\hline & & $\begin{array}{l}\text { Yolk protein } \\
\text { oxidation }\end{array}$ & $\begin{array}{l}\text { Albumen protein } \\
\text { oxidation }\end{array}$ \\
\hline Irradiation time & 4 & $171.0553533 * *$ & $279.606815^{* *}$ \\
\hline Thickness & 2 & $1.9436156^{* *}$ & $2.995096 * *$ \\
\hline Storage time (day) & 2 & $8.0992217 * *$ & $11.413469 * *$ \\
\hline $\begin{array}{l}\text { Irradiation time * } \\
\text { thickness }\end{array}$ & 8 & $1.3072028^{* *}$ & $1.599327 * *$ \\
\hline Irradiation time*day & 8 & $3.9301873 * *$ & $0.907437 * *$ \\
\hline Thickness*day & 4 & $0.1482414 *$ & $0.528334 * *$ \\
\hline $\begin{array}{l}\text { Irradiation time } \\
\quad * \text { thickness*day }\end{array}$ & 16 & $0.3432619 * *$ & $0.422492 * *$ \\
\hline \multicolumn{4}{|c|}{$*$ and $* *$ Significant at 5 and $1 \%$ level, respectively } \\
\hline \multicolumn{4}{|c|}{$\begin{array}{l}\text { Table } 9 \text { Duncan's Multiple Range Test results for effect of irradiation } \\
\text { time on protein oxidation }\end{array}$} \\
\hline Irradiation time (min) & Albur & men carbonyl (nmol) & Yolk carbonyl (nmol) \\
\hline 0 & 6.91 & $1542^{\mathrm{c}}$ & $8.87108^{\mathrm{c}}$ \\
\hline 3 & 7.59 & $469^{\mathrm{b}}$ & $7.45067^{\mathrm{d}}$ \\
\hline 5 & 12.41 & $1209^{\mathrm{a}}$ & $5.46185^{\mathrm{e}}$ \\
\hline 10 & 3.77 & $7075^{\mathrm{e}}$ & $11.83017^{\mathrm{b}}$ \\
\hline 15 & 5.68 & $3682^{\mathrm{d}}$ & $12.21837^{\mathrm{a}}$ \\
\hline
\end{tabular}

Number with the same letter are not significantly different

histidine, arginine, methionine, lysine, and cysteine, can be oxidized to carbonyl derivatives by oxidative stresses like irradiation (Butterfield et al. 1998). In accordance with Table 9, significant differences in protein oxidation value for albumen and yolk were observed due to irradiation $(P<0.05)$. Results indicated that irradiation time of up to $5 \mathrm{~min}$ caused unfavorable changes in protein characteristics of albumen. However, for higher irradiation times, protein oxidation decreased significantly. The lowest value $(3.771 \mathrm{nmol})$, even lower than that of the control, was observed in the $10 \mathrm{~min}$ treatment. For yolk, as irradiation time was increased, protein oxidation decreased to its minimum

Table 10 Duncan'sMultiple Range Test results for effect of storage time on protein oxidation

\begin{tabular}{lll}
\hline Storage time (day) & Albumen carbonyl (nmol) & Yolk carbonyl (nmol) \\
\hline 1 & $7.40836^{\mathrm{b}}$ & $8.01096^{\mathrm{b}}$ \\
2 & $6.71936^{\mathrm{c}}$ & $7.52168^{\mathrm{c}}$ \\
3 & $7.70014^{\mathrm{a}}$ & $8.36665^{\mathrm{a}}$ \\
\hline
\end{tabular}

Number with the same letter are not significantly different 
Table 11 Duncan's Multiple Range Test results for the effect of sample thickness on protein oxidation

\begin{tabular}{lll}
\hline Sample thickness (mm) & $\begin{array}{l}\text { Albumen carbonyl } \\
(\mathrm{nmol})\end{array}$ & Yolk carbonyl (nmol) \\
\hline 1 & $7.42064^{\mathrm{a}}$ & $7.99447^{\mathrm{b}}$ \\
2 & $7.42912^{\mathrm{a}}$ & $8.15881^{\mathrm{a}}$ \\
3 & $6.97809^{\mathrm{b}}$ & $7.74600^{\mathrm{c}}$ \\
\hline
\end{tabular}

Number with the same letter are not significantly different

value in the $5 \mathrm{~min}$ treatment $(5.462 \mathrm{nmol})$ followed by a subsequent increase. This may be attributed to increasing UVabsorption associated with increased irradiation time (Tombs and Maclagan 1962). Results in Fig. 3 for the first two irradiation times differ from those reported by Ma et al. (1990). According to their report, yolk proteins seem to be more susceptible to radiation induced breakdown than egg albumen proteins.

According to Table 10, carbonyl content in both albumen and yolk significantly differed as a function of storage time $(P<0.05)$. Due to the dramatic increase in microbial load after 4 days, durability of liquid eggs were assessed for 4 days. Protein oxidation in both albumen and yolk had its minimum value on the second day (Fig. 4). These results are in agreement with those reported by Badr (2006).

As Table 11 shows, minimum values of carbonyl content for both albumen and yolk were observed for $3 \mathrm{~mm}$ thick samples, which is expected and is due to the diminishing penetration of UV irradiation with increasing thickness.

Interaction effect of sample thickness and irradiation time on the carbonyl content of irradiated and non-irradiated liquid egg samples are shown in Table 12. Regarding albumen samples, irradiation treatments up to $5 \mathrm{~min}$ in three thicknesses caused a significant increase in carbonyl content $(P<0.05)$. However, carbonyl dramatically decreased to its minimum value $(3.2842 \mathrm{nmol})$ as irradiation time increased to $10 \mathrm{~min}$, even lower than that of the control, at $10 \mathrm{~min}$. The initial increase in protein oxidation of liquid egg albumen may be attributed to radiation-induced changes that resulted in less soluble aggregates in egg albumen. Our results were in agreement with those of Schuessler and Schilling (1984) who have reported that bovine serum albumin was cleaved by the oxidative destruction of proline residues, yielding specific protein fragments. Also, there have been reports on the aggregation
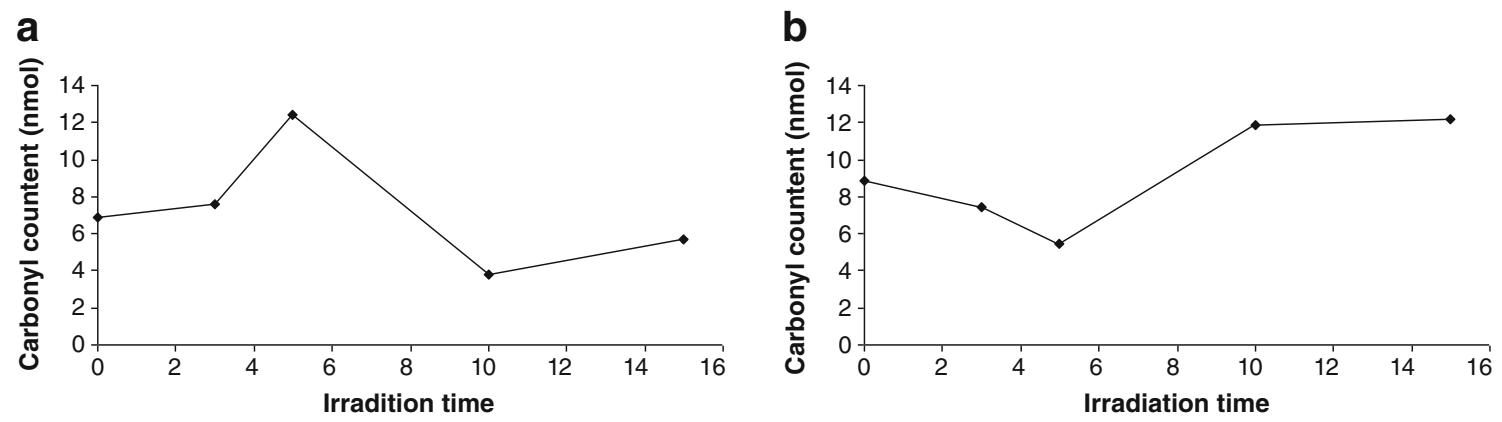

Fig. 3 Effect of irradiation time on protein oxidation for albumen (a) and yolk (b)
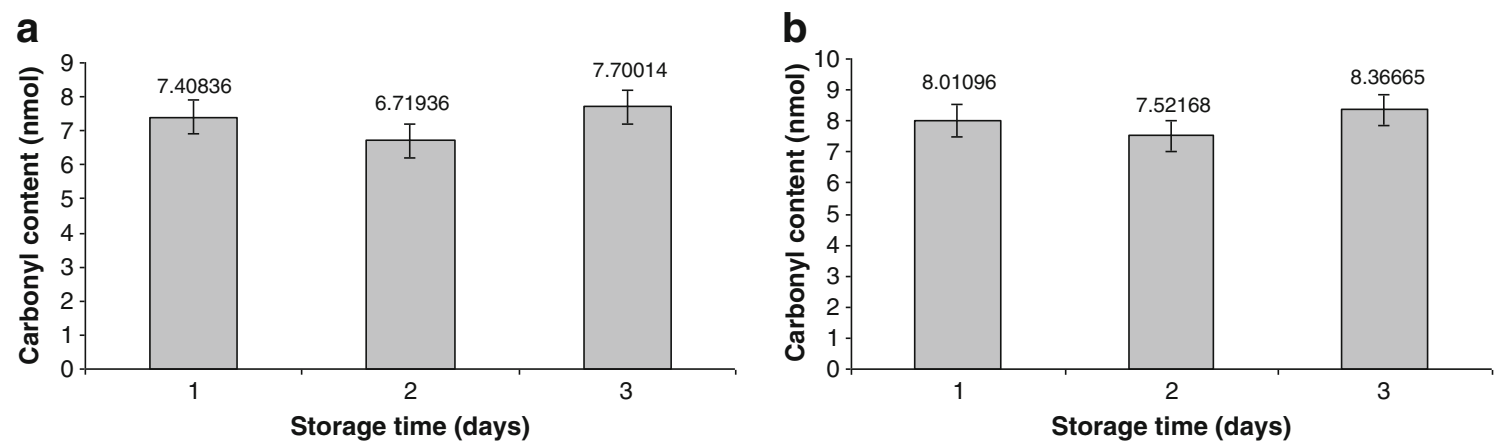

Fig. 4 Effect of storage on protein oxidation for albumen (a) and yolk (b) 
Table 12 Comparison of protein oxidation means as affected by irradiation time and thickness

\begin{tabular}{lcc}
\hline $\begin{array}{l}\text { Irradiation time } \\
\text { thickness }\end{array}$ & Albumen carbonyl (nmol) & Yolk carbonyl (nmol) \\
\hline $0(\min )^{*} 1(\mathrm{~mm})$ & $6.8292^{\mathrm{e}}$ & $8.9678^{\mathrm{b}}$ \\
$0 * 2$ & $6.8292^{\mathrm{e}}$ & $8.9678^{\mathrm{b}}$ \\
$0 * 3$ & $6.8292^{\mathrm{e}}$ & $8.9678^{\mathrm{b}}$ \\
$3 * 1$ & $7.7179^{\mathrm{c}}$ & $7.9448^{\mathrm{c}}$ \\
$3 * 2$ & $7.9681^{\mathrm{c}}$ & $7.5996^{\mathrm{c}}$ \\
$3 * 3$ & $7.0981^{\mathrm{d}}$ & $6.8076^{\mathrm{d}}$ \\
$5 * 1$ & $13.1063^{\mathrm{a}}$ & $5.8607^{\mathrm{ef}}$ \\
$5 * 2$ & $12.3499^{\mathrm{b}}$ & $5.5214^{\mathrm{fg}}$ \\
$5 * 3$ & $11.7801^{\mathrm{c}}$ & $5.0035^{\mathrm{g}}$ \\
$10 * 1$ & $3.2842^{\mathrm{i}}$ & $11.7393^{\mathrm{a}}$ \\
$10 * 2$ & $4.0165^{\mathrm{h}}$ & $12.0457^{\mathrm{a}}$ \\
$10 * 3$ & $4.0116^{\mathrm{h}}$ & $11.7055^{\mathrm{a}}$ \\
$15 * 1$ & $5.9069^{\mathrm{f}}$ & $5.7499^{\mathrm{ef}}$ \\
$15 * 2$ & $5.9819^{\mathrm{f}}$ & $6.6596^{\mathrm{d}}$ \\
$15 * 3$ & $5.1716^{\mathrm{g}}$ & $6.2456^{\mathrm{de}}$ \\
\hline
\end{tabular}

Number with the same letter are not significantly different

and cross-linking of proteins by irradiation (Puchala and Schessler 1993; Kume and Matsuda 1995). However, at 10 min irradiation time, covalent cross-linkages are formed between free amino acids and proteins, and between peptides and proteins in solution after irradiation (Garrison 1987) which may have contributed to higher absorbance at $280 \mathrm{~nm}$ and showed higher protein concentration. On the other hand, carbonyl in irradiated and non-irradiated liquid egg yolk rarely showed significant $(P<0.05)$ changes within groups as indicated in Table 12. Thus, interaction effect of sample thickness and irradiation time on albumen oxidation was mostly nonsignificant while for yolk was not, indicating the independence of albumen oxidation from sample thickness (Huang et al. 1997). Gaber (2005) irradiated protein with $0,0.5,1$, and $5 \mathrm{KGy}$ doses of gamma radiation. According to his results, the molecular weight of proteins exposed to the $0.5-\mathrm{kGy}$ radiation dose exhibited a minor change. However, a notable decrease in the molecular weight of protein was observed when exposed to $\gamma$-radiation at 1 and $5 \mathrm{kGy}$ where the $5 \mathrm{kGy}$ irradiation dose had higher protein weight compared with the $1 \mathrm{kGy}$ dose.

Regarding the interaction effect of irradiation time and storage times (Table 13), for each irradiation time, the carbonyl content of irradiated liquid eggs significantly decreased after 2 days of storage $(P<0.05)$. Furthermore, if compared with zero and 4 days of storage this is the lowest oxidation level. Having the best functional properties in the second day as well, points to this time as the best time for using liquid albumen in bakery.
Table 13 Comparison of protein oxidation means as affected by irradiation time and day

\begin{tabular}{lcc}
\hline $\begin{array}{l}\text { Irradiation time } \\
\text { day }\end{array}$ & $\begin{array}{l}\text { Albumen protein } \\
\text { oxidation }\end{array}$ & $\begin{array}{l}\text { Yolk protein } \\
\text { oxidation }\end{array}$ \\
\hline 0 (min)*1 (day) & $6.7230^{\mathrm{d}}$ & $8.1280^{\mathrm{d}}$ \\
$0 * 2$ & $6.9847^{\mathrm{de}}$ & $9.2007^{\mathrm{c}}$ \\
$0 * 3$ & $7.0386^{\mathrm{d}}$ & $9.2845^{\mathrm{c}}$ \\
$3 * 1$ & $8.2143^{\mathrm{c}}$ & $7.1805^{\mathrm{e}}$ \\
$3 * 2$ & $6.6402^{\mathrm{ed}}$ & $6.9294^{\mathrm{ef}}$ \\
$3 * 3$ & $7.9295^{\mathrm{c}}$ & $8.2421^{\mathrm{d}}$ \\
$5 * 1$ & $12.5345^{\mathrm{a}}$ & $6.5532^{\mathrm{fg}}$ \\
$5 * 2$ & $11.8459^{\mathrm{b}}$ & $4.6375^{\mathrm{i}}$ \\
$5 * 3$ & $12.8559^{\mathrm{a}}$ & $5.1949^{\mathrm{h}}$ \\
$10 * 1$ & $3.6933^{\mathrm{i}}$ & $11.7918^{\mathrm{ab}}$ \\
$10 * 2$ & $3.3076^{\mathrm{i}}$ & $11.5092^{\mathrm{b}}$ \\
$10 * 3$ & $4.3114^{\mathrm{h}}$ & $12.1895^{\mathrm{a}}$ \\
$15 * 1$ & $5.6151^{\mathrm{f}}$ & $6.4012^{\mathrm{g}}$ \\
$15 * 2$ & $5.0801^{\mathrm{g}}$ & $5.3317^{\mathrm{h}}$ \\
$15 * 3$ & $6.3653^{\mathrm{e}}$ & $6.9223^{\mathrm{ef}}$ \\
\hline
\end{tabular}

Number with the same letter are not significantly different

Functional properties

Since the effect of sample thickness on protein oxidation was not significant, the albumen foam ability and foam stability experiments were carried out only in $1 \mathrm{~mm}$ thickness level. Initial irradiation produces the free radicals which can cause protein oxidation. Protein oxidation at this stage would increase foam ability while, decreasing foam stability. As irradiation goes further, chain scission would have happened. These changes can impact the functional properties of proteins and may influence them for albumen. Although, UV irradiation, except for the 10 min treatment, did not show any significant effect on foam ability and foam stability, however, results indicate that, irradiation improved foam ability and foam stability of albumen (Table 14). Our results were in agreement with Ma et al. (1990) who reported that foam ability was improved by gamma irradiation due to conformational changes of proteins in egg white, which increased surface hydrophobicity and lowered viscosity.

Table 14 Results of Duncan's Multiple Range Test on the effect of irradiation time on functional properties

\begin{tabular}{lrrrrr}
\hline Source of variations & \multicolumn{4}{l}{ Irradiation time } \\
\cline { 2 - 6 } & 0 & 3 & 5 & 10 & 15 \\
\hline Foam ability & $1.93^{\mathrm{b}}$ & $2.05^{\mathrm{b}}$ & $1.93^{\mathrm{b}}$ & $2.33^{\mathrm{a}}$ & $2.13^{\mathrm{ab}}$ \\
Foam stability & $75.46^{\mathrm{ab}}$ & $75.33^{\mathrm{ab}}$ & $79.60^{\mathrm{a}}$ & $63.33^{\mathrm{c}}$ & $72.00^{\mathrm{b}}$ \\
\hline
\end{tabular}

Number with the same letter are not significantly different 


\section{Conclusions}

- There were significant differences between irradiated and non-irradiated liquid eggs in terms of bacterial activity and protein oxidation in both yolk and albumen $(P<0.001)$.

- After the first 2 days, total Salmonella and protein oxidation of liquid eggs decreased only in $5{ }^{\circ} \mathrm{C}$ treatment which indicated that the best temperature for storage of liquid egg is $5^{\circ} \mathrm{C}$.

- The lowest count of bacteria in albumen and yolk was observed at 15 and $10 \mathrm{~min}$ irradiation times in 3 and $2 \mathrm{~mm}$ thickness levels during the first 2 days, respectively.

- The best irradiation time to improve foamability and stability of albumen and were 10 and $5 \mathrm{~min}$, respectively.

- The optimum irradiation time according to bacterial activity, protein oxidation and functional properties was for $10 \mathrm{~min}$.

\section{References}

Al-bachir M, Zeinou R (2006) Effect of gamma irradiation on some characteristics of shell eggs and mayonnaise prepared from irradiated eggs. J Food Saf 26:348-360

Anonymous (1993) The egg products regulations 1993, Statutory Instrument No. 1520. HMSO, London

Anton M, Chapleau N, Beaumal V, Delepine S, Lamballerie-Anton MD (2001) Effect of high-pressure treatment on rheology of oil-in-water emulsions prepared with hen egg yolk. Innov Food Sci Emerg Technol 2:9-21

AOAC (1996) Official methods of analysis. Association of Official Analytical Chemists, Washington

Badr HM (2006) Effect of gamma radiation and cold storage on chemical and organoleptic properties and microbiological status of liquid egg white and yolk. Food Chem 97:285-293

Blumenthal D (1990) Salmonella entertains from the chicken to the egg. FDA Consum 24(3):6-10

Butterfield DA, Koppal T, Howard B, Subramaniam R, Hall N, Hensley K, Yatin S, Allen K, Aksenov M, Aksenova M, Carney J (1998) Structural and functional changes in proteins induced by free radical-mediated oxidative stress and protective action of the antioxidants N-tert-butyl- $\alpha$-phenylnitrone and vitamin E. Ann New York Acad Sci 854:448-462

Durante RW (2002) Food processors requirements met by radiation processing. Radiat Phys Chem 63:289-294

Gaber MH (2005) Effect of $\gamma$-irradiation on the molecular properties of bovine serum albumin. J Biosci Bioeng 100(2):203-206

Garrison WM (1987) Reaction mechanisms in the radiolysis of peptides, polypeptides and proteins. Chem Rev 87:381-398

Hidalgo A, Rossi M, Clerici F, Ratti S (2008) A market study on the quality characteristics of eggs from different housing systems. Food Chem 106:1031-1038

Huang S, Herald TJ, Mueller DD (1997) Effect of electron beam irradiation on physical, physicochemical, and functional properties of liquid egg yolk during frozen storage. Poult Sci 76:1607-1615
Koehler B, Huebner H, Krautschick M (1989) Use of irradiation for decontamination of chicken and spray-dried whole egg powder from salmonellae. Z Ges Hyg 35(11):665-668

Kume T, Matsuda T (1995) Changes in the structural and antigenic properties of proteins by radiation. Radiat Phys Chem 46:225-231

Liu XD, Jang A, Kim DH, Lee BD, Lee M, Jo C (2009) Effect of combination of chitosan coating and irradiation on physicochemical and functional properties of chicken egg during room-temperature storage. Radiat Phys Chem 78:589-591

Ma CY, Sahasrabudhe MR, Poste LM, Harwalkar VR, Chambers JR (1990) Gamma irradiation of shell eggs: internal and sensory quality, physicochemical characteristics, and functional properties. Can Inst Food Sci Technol J 23:226-232

Meszaros L, Horti K, Farkas J (2006) Changes of hen eggs and their components caused by non-thermal pasteurizing treatments I. Gamma irradiation of shell eggs. Acta Aliment 35:229-236

Molins RA, Motaremi Y, Kaferstein FK (2001) Irradiation: a critical control point in ensuring the microbiological safety of raw foods. Food Control 12:347-356

Morehouse KM (2002) Food irradiation-US regulatory considerations. Radiat Phys Chem 63:281-284

Nigro F, Ippolito A, Lattanzio V, Di Venere D, Salerno M (2000) Effect of ultraviolet-C light on postharvest decay of strawberry. J Plant Pathol 82(1):29-37

Perez OE, Pilosof AMR (2003) Influence of pulsed electric field processing on the structure and gelation of egg white. In: Dickinson E, Vliet TV (eds) Food colloids, biopolymers and biomaterials. RSC, Cambridge, pp 119-132

Piga A, D'hallewin G, D'Aquino S, Agabbio M (1997) Influence of film wrapping and UV irradiation on cactus pear quality after storage. Packag Technol Sci 10:59-68

Probola G, Zander L (2007) Application of PCA method for characterisation of textural properties of selected ready-to-eat meat products. J Food Eng 83:93-98

Puchala M, Schessler H (1993) Oxygen effect in the radiolysis of proteins. Int J Radiat Biol 64:149-156

Redmond EC, Griffith CJ (2003) Consumer food handling in the home: a review of food safety studies. J Food Prot 66(1):130-161

Rossi M, Casiraghi E, Primavesi L, Pompei C, Hidalgo A (2010) Functional properties of pasteurised liquid whole egg products as affected by the hygienic quality of the raw eggs. LWT-Food Sci Technol 43(3):436-441

Schuessler H, Schilling K (1984) Oxygen effect in the radiolysis of proteins. Int J Radiat Biol 45:267-281

Serrano LE, Murano EA, Shenoy K, Olson DG (1997) D values of Salmonella enteritidis isolates and quality attributes of shell eggs and liquid whole eggs treated with irradiation. Poult Sci 76:202-205

Song HP, Kim B, Choe JH, Jung S, Kim KS, Kim DH, Jo C (2009) Improvement of foaming ability of egg white product by irradiation and its application. Radiat Phys Chem 78:217-221

Tombs MP, Maclagan NF (1962) The Effect of hydrolysis of proteins on their ultraviolet-absorption spectra near $210 \mathrm{~nm}$. Biochem J 84:1

Van der Plancken I, Van Loey A, Hendrickx M (2005) Changes in sulfhydryl content of egg white proteins due to heat and pressure treatment. J Agric Food Chem 53:5726-5733

Vuorela S, Salminen H, Makela M, Kivikari R, Karonen M, Heinonen M (2005) Effect of plant phenolics on protein and lipid oxidation in cooked pork meat patties. J Agric Food Chem 53:8492-8497 